\title{
A Comparative Study of Damages and Price Reduction Remedy for Breach of Sale Contract under CISG, English and Iranian Laws
}

\author{
Ali Zareshahi ${ }^{1}$ \\ ${ }^{1}$ Department of Law, Maybod Branch, Islamic Azad University, Maybod, Iran \\ Correspondence: Ali Zareshahi, Department of Law, Maybod Branch, Islamic Azad University, Maybod, Iran. \\ E-mail: zareshahi.a94@gmail.com
}

Received: February 8, 2016

Accepted: May 19, 2016 Online Published: November 30, 2016

doi:10.5539/jpl.v9n10p126

URL: http://dx.doi.org/10.5539/jpl.v9n10p126

\begin{abstract}
In order to discourage people from breaching a contract and also to compensate the injured party for any losses, the law provides several remedies for breach of contract. One of these remedies is price reduction. In this study, we aims to compare the rules of Iranian law for price reduction remedy with those provided by Convention on Contracts for the International Sale Of Goods (CISG), and English law. English law has set detailed rules for rewarding damages for breach of contract, while Iranian law has generally-defined rules. The legislator has not determined not only the types of damage, but also the criteria for assessment of the damage. The remedies provided for price reduction in the CISG for breach of contract has been adapted to requirements of international trade, while In Iranian law there is no clear rules for this purpose, except three rules including a) Giving property to the buyer instead of money, (b) Compensation for loss of legitimate business involved to the buyer, and (c) Compensation for delayed payment to the buyer.
\end{abstract}

Keywords: damage, price reduction, Iranian law, English law, contracts for the International sale of goods, CISG

\section{Introduction}

The available remedies for breach of contract are a particularly important, if not a decisive factor in the choice of law for parties engaging in the international sale of goods. This is especially the case for the buyer, who invests time and money to research, enquire, negotiate and enter into an international sale contract with a foreign seller, and would like to be assured that if anything goes wrong or the seller deliberately breaches the contract, his remedies under the applicable law will provide him with satisfactory relief. The available remedies for breach of contract are also particularly important for the lawyers advising buyers entering into international sales contracts (Agapiou, 2016). In order to discourage people from breaching a contract and also to compensate the injured party for any losses, the law provides several remedies for breach of contract such as damages, specific performance, contract recession, price reduction and contract modification which are monetary awards. Damage refers to monetary compensation that is claimed by a person or awarded by a court in a civil action to a person who has been injured or suffered loss because of the wrongful conduct of another party. Price reduction is a remedy that is useful to the buyer as an independent right coexisting with the right to claim damages provided for in Article 45(1)(b) of Convention on Contracts for the International Sale Of Goods (CISG), and yet relatively unknown in common law. In terms of article 45 of CISG, if the seller should fail to perform any of its obligations under the contract or the CISG, the buyer may exercise the rights provided in articles 46 to 52 of the convention and in addition to that claim damages as provided for in article 74 to 77. In terms of article 46(1) of the CISG, the buyer is entitled to require performance by the seller of his obligations unless the buyer has resorted to a remedy which is inconsistent with this requirement. A remedy which would be inconsistent with specific performance would be any remedy aimed at avoidance or cancellation of the agreement.

Many studies have been conducted on CISG law and the laws of other countries related to the remedies of contractual breach. Eiselen (2001) compared the remedies for breach of contract under the CISG and South African Law, and concluded that the remedies provided for in the CISG upon a breach of contract, are quite similar to those provided for in the South African law of contract. Piliounis (2000) studied the remedies of specific performance, price reduction and additional time under the CISG and compared them with remedies provided for in English law. He stated that the basis of English sale of goods law is the Sales of Good Act 1979 
(SGA) whose concept is old, while the CISG is a much more modern document which led to some ambiguity and uncertainty in application. The remedies of specific performance, price reduction and additional time which are introduced by the CISG are different from or new to English law. In other similar study, Majdzadeh Khandani (2012) compared the differences between CISG and English law in terms of specific performance and revealed that the main remedy granted by English courts is confined to damages, as they recognize specific performance as a discretionary order. Agapiou (2016) study the differences between the buyer's remedies in the CISG and English sales law. He concluded that the seller's rights to cure under the CISG are more extensive than the seller's right to cure under English sales law. Also, he argued that English sales law does not provide a general buyer's remedy of price reduction. In another studies Sondahl (2003) and Shin (2005) analyzed CISG Article 50 remedy of the reduction of the price and its problems in applying price reduction. Considering previous studies, in this comparative study, our purpose is to study price reduction as the remedies for breach of contract, under English law and CISG law and compare it with Iranian law.

\section{Damage for Breach of Contract}

Damage is the most adequate remedy when there is a contract for sale of goods which are readily available in the market (Treitel, 1998). Under Article 45(1)(b) of CISG, the buyer has the right to claim damages If the seller fails to perform any of his obligations under the contract or this Convention. Some of main types of damages for breach of contract in English law are:

\section{A. Compensatory Damages}

These are damages for a monetary amount that is intended to compensate the non-breaching party for losses that result from the breach. The aim is to "make the injured party whole again". There are two types of compensatory damages:

- Expectation Damages: These are damages that are intended to cover what the injured party expected to receive from the contract. Calculations are usually straightforward as they are based on the contract itself or market values.

- Consequential Damages: These are intended to reimburse the injured party for indirect damages other than contractual loss; for example, loss of business profits due to an undelivered machine. In order to recover, the injuries must "flow from the breach," i.e. be a direct result of the breach, and be reasonably foreseeable to both parties when they entered into the contract. (Tam, 2016)

\section{B. Pecuniary and non-pecuniary damages}

"Pecuniary damages are generally assessed on the basis of calculable losses for items such as the plaintiff's prospective loss of earnings and profits and costs of future care, as well as other expenses. In contrast, non-pecuniary damages cannot be arithmetically calculated because they compensate the plaintiff for intangible losses arising from physical and psychological pain and suffering as well as from any loss of amenities or expectations of life" (McIntyre v. Docherty, 2009).

\section{Liquidation Damages}

Damages agreed upon by the parties entering into a contract, to be paid by a party who breaches the contract to a non-breaching party. These are available when damages may be hard to foresee and must be a fair estimate of what the damages might be if there is a breach. Liquidated damages may be used when it would be hard to prove the actual harm or loss caused by a breach. The amount of liquidated damages must be a reasonable estimate of the actual damages that a breach would cause. A contract term setting unreasonably large or disproportionate liquidated damages may be void because it constitutes a penalty or punishment for default.

\section{Punitive Damages}

These are damages that intend to punish the breaching party and to deter him or her from committing any future breaches (Fleming, 1985). They are rarely awarded in contract cases, though they may be available in some fraud or tort cases that overlap with contract law.

\section{E. Nominal Damages}

These are damages that are awarded when the injured plaintiff does not actually incur a monetary loss, but the judge wants to show that the winning party was in the right. These are typically rarely awarded in contract cases because breaches of contract usually involve some sort of loss to one party, however they might be awarded in tort cases that cross over with a breach of contract case. 


\section{F. Restitutionary damages}

These are not really legal damages, but rather are an equitable remedy awarded to prevent the breaching party from being unjustly enriched. For example, if one party has delivered goods but the other party has failed to pay, the party that delivered the goods may be entitled to restitution, i.e. the cost of the delivered goods, in order to prevent the unjust enrichment.

Common use of restitution that shows the failure of other types of damage in English law and the inefficacy of the rules for remedy of contractual breach in Iranian law, is in breach of intellectual property contracts. In such contracts, their breach may not involve any loss to the other party, even though the violator can earn income more than the plaintiff by the breach of contract; As a result, in practice, the plaintiff has received no damage, but the defendant has benefited from the breach.

According to CISG:

"Damages for breach of contract by one party consist of a sum equal to the loss, including loss of profit, suffered by the other party as a consequence of the breach. Such damages may not exceed the loss which the party in breach foresaw or ought to have foreseen at the time of the conclusion of the contract, in the light of the facts and matters of which he then knew or ought to have known, as a possible consequence of the breach of contract" (Article 74);

In English law, claiming damages from the seller by the buyer is only possible if the buyer has not attempted to terminate the contract. Section 11(4) of the SGA states that:

"Where a contract of sale is not severable and the buyer has accepted the goods or part of them, the breach of a condition to be fulfilled by the seller can only be treated as a breach of warranty, and not as a ground for rejecting the goods, and treating the contract as repudiated, unless there is an express or implied term of the contract to that effect".

There is ambiguity in some provisions of CISG for their application, while the main remedy granted by English law for breach of contract is damages and it considers the test of inadequacy of damages and the uniqueness to avoid the unfair results (Majdzadeh Khandani, 2012).

\section{Price Reduction}

The remedy of price reduction is an alternative remedy to the claim for damages, especially in those circumstances where payment has not been effected. Price reduction is a traditional civil law remedy that derives from actio quanti minoris in Roman law (Bergsten \& Miller, 1979). Unlike damages-based remedies, the principle of the price reduction remedy is not dependent on actual loss being suffered by the buyer, but is solely dependent on the abstract relationship between the actual value of the goods delivered and the hypothetical value of conforming goods (Piliounis, 2000). CISG Article 50 provides for the rules that govern the principle of price reduction. In terms of Article 50 of CISG,

"If the goods do not conform with the contract and whether or not the price has already been paid, the buyer may reduce the price in the same proportion as the value that the goods actually delivered had at the time of the delivery bears to the value that conforming goods would have had at that time. However, if the seller remedies any failure to perform his obligations in accordance with article 37 or article 48 or if the buyer refuses to accept performance by the seller in accordance with those articles, the buyer may not reduce the price". (UNCITRAL, 2010, p.16)

According to the Article 50 of CISG, price reduction plays an especially important role because it allows the buyer to reduce the price before it has paid. It may not be subject to a "reasonable time" requirement ( Sondahl, 2003). The principle underlying price reduction is that the buyer may keep non-conforming goods delivered by the seller in which case the contract is adjusted to the new situation. Price reduction should therefore be regarded as an adaptation of the contract not as an award of damages (Eiselen, 2001). Shin (20005) argues that article 50 does not make any explicit requirement for a separate declaration for reduction of price, and its legislative history supports the view that the drafters decided not to include the requirement in the provision, as correctly explained by commentators.

In English law, general remedy of price reduction can be found in section 30 of SGA.

"Where the seller delivers to the buyer a quantity of goods less than he contracted to sell, the buyer may reject them, but if the buyer accepts the goods so delivered he must pay for them at the contract rate." (section 30(1)) 
For example, if the seller has delivered less than the contracted quantity of goods and the buyer accepts the goods, the buyer must "pay for them at the contract rate." The reference to "contract rate" is comparable to the "proportional" calculations made under Article 50 of the CISG. So, section 30 of SGA would likely reach the same result of calculation as Article 50. Section 53 of SGA also contemplates a similar concept to Article 50, though it applies only to breaches of warranty and is phrased in terms of setting off the breach against the price due: (Piliounis, 2000)

"The measure of damages for breach of warranty is the estimated loss directly and naturally resulting, in the ordinary course of events, from the breach of warranty...In case of breach of warranty of quality such loss is prima facie the difference between the value of the goods at the time of delivery to the buyer and the value they would have had if they had fulfilled the warranty." (Section 53(2) and (3))

Unlike the CISG, there is no general right on the part of the buyer to reduce the price unless set up as a defence to the seller's action for the price; However, as with the CISG, the reduction of price remedy applies at the option of the buyer in lieu of a claim for damages. Even without a specific remedy comparable to Article 50, English law probably reaches the same result as the CISG in most cases where there is a breach of a warranty. (Piliounis, 2000). the circumstances under the CISG where the price reduction remedy of Article 50 differs from of damages, and the same difference would hold true between Article 50 and damage awards under the SGA is where the buyer accepts the goods and (1) the buyer is unable to prove damages, (2) force majeure, and (3) the market price of conforming goods increases between the time of the contract and the time of delivery (Ibid.)

\section{Discussion}

\subsection{Damage in Iranian Law}

In Iran, damages are limited to losses which the injured party actually suffered. Damages for loss of profits are typically not awarded. However, aggrieved parties may recover the cost of obtaining substitute performance. Whether this includes damages for delay is unclear. However, the Shari'a in general does not allow recovery of damages for delayed performance (Saleh, 1989). Rules related to damages in Iranian law can be found in Chapter 3, subsection 2 of Civil Code Act 1928. Unfortunately, in this section, only a few articles are about the damages and they have only outlined some conditions, impediments and problems of receiving the compensations (Articles 226 to 230). In Article 226, the legislator has comprehensively determined the conditions for receiving compensation for damage:

"In the event of non-fulfilment of an undertaking by one party, the other party cannot claim damages for loss sustained, unless a special period was fixed for fulfilment of the undertaking and that period was expired. If no period was fixed for the fulfilment of the undertaking a party can only claim damages if the power for fixing the period for such fulfilment was vested in him and if he proves that he asked for the fulfilment of the obligation."

Other conditions that create the right to claim damages in Iranian law are the loss involvement, causality, certainty, predictability and directness (Shahidi, 2004). In articles 227 and 229, the legislator indicates to the conditions when the party can not be convicted to compensate for damages. Article 228 stated one of rules for damage remedy which is" delay in the payment", and Article 230 addresses the payment obligation:

"If in a contract the amount of compensation to be in the event of its non-fulfilment is laid down, the judge can condemn the offender to pay more or less than the sum fixed."(Article 230)

It seems that this low number of defined rules in Iranian law cannot be sufficient especially when with the increasing needs for economy and development of transactions and exchanges, particularly at the international level, the damage topic and its assessment criteria have become very important. This necessitates the structural reform of Iranian law and setting up of a comprehensive system for the breach of a contract by damage remedy. To do this, first, different types of compensatory damages in Iranian law should be explicitly determined. Two clear examples are "loss of profit" and "ethnical damages" which the legislator has not acted about them with certainty. In terms of loss of profit, considering article 728 of the former Civil Procedure Code, clause 2 of article 515 of the new Civil Procedure Code, and article 9 of the Code of Criminal Procedure which is based on a famous juristic statement that says that loss of profit is not compensable (Naraghi, 1990), many theoretical disputes have raised on this issue, and have led to many interpretations (Samet, 1998). This act of the legislator is contrary to the principle of full compensation and does not match the current international practice. The most prestigious international documents have considered the loss of profit as a compensatory damage e.g. Article 74 of the CISG, paragraph 1 of articles 2, 4 and 7 of the International Commercial Contracts, and article 502:9 of European Contract Law. Also, about the ethnical damage in Iranian law, article 212 of General Penal Code, 
article 4 of the Criminal Procedure Amendment Act 1953, article 9 of the Code of Criminal Procedure 1950, and article 171 of Constitution law regarding the acceptance of ethnical damages on one hand, and viewpoints of Guardian Council about the non-religiousness of ethnical damages reflected in clause 1, article 30 of Press Law 1985, and article 58 of the Islamic Penal Code on the other hand, Have created many disputes in this area. In addition to all these differences about types of compensatory damages in Iranian Law, the attitude of legislator in article 221 of Civil Code about the existence of the right to receive damage awards is skeptic:

"If any party undertakes to perform or to abstain from any act, he is responsible to pay compensation to the other party in the event of his not carrying out his undertaking provided the compensation for such losses is specified in the contract or is understood in the contract according to customary law or provided such compensation is by law regarded as guaranteed."

To make the damage remedy for breach of contracts structural, as said before, the legislator first should clarify the types of the compensatory damages and present the criteria for assessment of these compensatory damages to remove their unpredictability ; so parties can properly assess risks and contractual limits and size and to cover the risks using tools such as insurance.

\subsection{Price Reduction in Iranian Law}

In Iranian law, there are no specific rules on awarding price reduction for breach of contracts. For this purpose, the following solutions have been proposed:

(1). Property instead of money: By virtue of article 262 of Civil Code of Iran which says:

"The purchaser of the property shall have the right to claim from the man who sold it to him without authority for the return of the actual consideration, or a property identical there to, or its equivalent in value."

Also, in majority of contracts in Iran, price is paid as money, and renowned jurists consider money as a credit property and consider it as "fungible property" and, though have different points, the purchasing power affects the fungibility of money, Therefore, in this respect, when the buyer claims against non-owner seller for the return of price, assuming that the actual money has been transferred to others by the customer, the seller should return the actual consideration. This is fulfilled when the seller gives the customer property as much as to compensate the price reduction and not only to the extent that the customer has already paid to him (Safaei \& Pour Abdullah, 2013).

(2). Compensation for loss of legitimate business: For example, in case of sale by the non-owner and third party's claim ownership, the seller may has deprived the customer of legitimate business and its benefits by selling another person's property to the buyer in good faith, because the buyer has thought that with the assets (capital) of his time, he will make a profitable deal for the future, and he has spent its capital for this deal, and has been deprived of the possibility of any other transaction. So, in addition to the return of the price to the buyer, the seller should pay the loss and damage caused by loss of legitimate business to him. In support of this solution, article 46 and 47 of the constitution of Iran states that everyone is the owner of the income from his own legitimate business and labor, and no one can, under the pretext of his own ownership, deprive another person from the opportunity to work. Private ownership which is legitimately acquired must be respected and its violation must be avoided. Furthermore, under article 1 of Iranian law on Civil Liability Act of 1960, which states that whoever internationally and without legal authority damages to another's life, health, property, freedom , business reputation or any other right, and causes a material or spiritual damage to the another is responsible for damage caused by the action. So, in this respect, non-owner seller who has deprived the buyer from his or her own business is responsible for the damage suffered by the buyer, because having legitimate business for income is a right that that has been established for individual under the constitution.

(3). Compensation for delayed payment: By assuming that in cases of sale by the non-owner and breach of contract by the owner, the contract of sale will be invalid, and the goods should be returned to the owner, and the price to the buyer; therefore, at the time invalidating the purchase, the seller is obliged to return the price to the buyer. About the calculation of damage, Article 522 of Iran's Civil Procedure Code of the Public and Revolutionary Courts approved in 2000 states that in case of a considerable change in annual price index, according to Central Bank, damage for delayed payment of price is calculated from the maturity date until the date of payment to the customer (Safaei, 2003). 


\section{Conclusion}

In this paper our purpose was to compare the CISG and English law price reduction remedy of contractual breach with Iranian law. Before the Islamic Revolution in 1979, Iran was influenced by the French and German civil codes. Today, as a result of the Revolution, its legal system is a mix of civil and Islamic law, however all laws in Iran are required to follow Islamic law.

In comparing Iranian law with English law, we can say that English law has set detailed rules for rewarding damages for breach of contract which cause the determination of full compensation become more accurate. In dealing with damage remedy, Iranian law has generally-defined rules. The legislator has not determined not only the types of damage, but also the criteria for assessment of the damage. Also it has not strictly considered even the compensatory principle in breach of contracts. It seems that In Iranian law, receiving punitive damage for breach of contractual obligations has not foreseen, but when the damage was significantly more than the losses that were expected to be achieved from breach of contract., the compensatory aspect of "Penalty clause" (Vajhe eltezam) which is a remedy for breach of contract in Iranian law, would become punitive. In Iranian law, unlike English law, due to the existence of the Principle of La Zarar (no-harm), there is no defined nominal damage. So the breach of contract by the obligor without involving loss to the obligee will not be entitled to remedy. That is why the "necessity of loss occurrence" is one of the conditions for creating the right to receive compensation for breach of contract.

In comparing Iranian law with CISG law, the remedies provided for price reduction in the CISG for breach of contract has been adapted to requirements of international trade, while In Iranian law there is no clear rules and instead, three rules have been provided which the seller has been obliged to do in case of contractual sale breach including (a) Giving property to the buyer instead of money, (b) Compensation for loss of legitimate business involved to the buyer, and (c) Compensation for delayed payment to the buyer.

\section{References}

Agapiou, N. (2016). Buyer's remedies under the cisg and english sales law: a comparative analysis. PhD thesis, School of Law, University of Leicester, UK.

Bergsten, E. E., \& Miller, A. J. (1979). The Remedy of Reduction of Price. The American Journal of Comparative Law, 27(2/3), 255-57. https://doi.org/10.2307/840032

Eiselen, S. (2001). A Comparison of the Remedies for Breach of Contract under the CISG and South African Law. In: Basedow et al. ed., Aufbruch nach Europa-- 75 jahre Max-Planck-Institut für Privatrecht, Mohr Siebeck: Tübingen. Retrieved from http://www.jus.uio.no/pace/en/html/a_comparison_of_remedies_for_breach_of_contract_under_cisg_and_s outh_african_law.siegfried_eiselen.html

Fleming, J. G. (1985). An Introduction to the Law of Torts. Oxford: Clarendon Press.

Majdzadeh Khandani, K. (2012). Does the CISG, compared to English law, put too much emphasis on promoting performance of the contract despite a breach by the seller? Manchester Law Review, 1, 98-135.

McIntyre v. Docherty. (2009). ONCA 448. Retrieved June 19, 2016, from http://www.canlii.org/en/on/onca/doc/2009/2009onca448/2009onca448.html

Naraghi, M. A. (1990). Eawayid alayam fi bayan qawaeid alahkam wamuhammat masayil alhilal walharam [compensates according to the rules of Jurisprudence and tasks of halal and haram]. Qom: Islamic Propagation Office. [In Arabic]

Piliounis, P. A. (2000). The Remedies of Specific Performance, Price Reduction and Additional Time (Nachfrist) under the CISG: Are these worthwhile changes or additions to English Sales Law? Pace International Law review, 12(1), 1-46.

Safaei, H., \& Pour Abdullah, M. (2013). Asare Hoghogie Edeaye Malekiate Shakhse Sales Nesbat be Mobaya dar Hoghoghe Iran, Mesr, va Englis, [The legal effect of third-party claim against the object of sale in Iran, Egypt, ENGLISH laws]. Majaleye Hoghoghi Dadgostari, 77(81), 37-64. [In Persian]

Safaei, S. H. (2003). Doreye Moghadamatie Hoghoghe Madanie Ghavaede Omomie Gharardadha [Foundation Course of General Rules of Civil Rights of Contracts]. Tehran: Mizan [In Persian]

Sale of Goods Act. (1979). Hetrieved http://www.legislation.gov.uk/ukpga/1979/54/pdfs/ukpga_19790054_en.pdf

Saleh, N. (1989). Remedies for Breach of Contract under Islamic and Arab Laws. Arab Law Quarterly, 4(4), 
269-290. https://doi.org/10.1163/157302589X00136

Samet, M. A. (1998). Fote manfa'at ya adamon-naf'e dar hoghoghe Iran va Islam [Loss of Profit Iranian and Islamic Law]. Tehran University Journal of Law and Political Science, 42, 53-76. [In Persian]

Shahidi, M. (2004). Hoghoghe Madani: Asare gharardadha va ta'ahodat [Civil Code: The Effects of Contracts and Obligations] (2nd ed.). Tehran: Majd Cultural and Scientific Assembly. [In Persian]

Sondahl, E. (2003). Understanding the Remedy of Price Reduction - A Means to Fostering a More Uniform Application of CISG. Vindobona Journal of International Commercial Law and Arbitration, 7(2), 255-276

Tam, J. (2016). Types of Damages Available for Breach of Contract. Retrieved from http://www.legalmatch.com/law-library/article/types-of-damages-available-for-breach-of-contract.html

The Civil Code Of The Islamic Republic of Iran. (1928). Retrieved from http://www.alaviandassociates.com/documents/civilcode.pdf

Treitel, G. H. (1988). Remedies for Breach of Contract: A Comparative Account. Oxford: Clarendon Press. https://doi.org/10.1093/acprof:oso/9780198255000.001.0001

United Nations Convention on Contracts for the International Sale of Goods (CISG). (1980). Retrieved from https://www.uncitral.org/pdf/english/texts/sales/cisg/V1056997-CISG-e-book.pdf

\section{Copyrights}

Copyright for this article is retained by the author(s), with first publication rights granted to the journal.

This is an open-access article distributed under the terms and conditions of the Creative Commons Attribution license (http://creativecommons.org/licenses/by/4.0/). 